\title{
The Relation of the Teacher and the Social Worker
}

\author{
By Anna Beach Pratt \\ Director, the White-Williams Foundation
}

$I^{\mathrm{N}}$ $\mathrm{N}$ thelaboratory experiments of these days where each factor and all the conditions are controlled, it is not such a difficult matter to analyze and evaluate results; but in experiments with human beings where the factors have not yet been clearly differentiated by science and where the conditions are only partially controlled, an analysis of results may be interpreted in a different way by each observer. When there is added to this difficulty, the brief time of four years for an experiment that should extend over the child's entire school life before an ultimate interpretation of any part of it is attempted, the reader will understand how tentative must be the findings of this paper.

It was not primarily to study the relation of the social worker to the teacher that the experiment was begun. Indeed, the teacher was not even a part of the experiment when the century old Magdalen Society of Philadelphia, now the White-Williams Foundation, decided that forming was more profitable than reforming, and so started out to seek the girls who were leaving school for industry before they were ready to meet the problems of store or factory.

By guiding the girl to the work adapted to her ability; by going to the factory with her in a figurative, and sometimes in a literal, sense; by understanding her home and her neighborhood background and by helping her to secure what she needed to round out her life in and out of the factory, it was hoped to keep her from the necessity of a Magdalen Home.

One of the first facts disclosed by this undertaking, was that many of the children were going to work for other reasons than poverty. Often some foolish reason was making them give up school.

In 1920 the White-Williams counselors in the Junior Employment Service of the Board of Public Education interviewed 908 of the $\mathbf{1 0 , 6 7 4}$ children who came that year to the Board of Public Education for general working certificates. Forty-seven per cent of these did not want to go on with their school work. They gave as reasons: "I was "left down",; "I didn't like arithmetic"; "I was too tall for the other girls in the room," etc. Many of these difficulties might have been adjusted if someone could have made plans with the children while they were still in school.

Even before these statistics were gathered, the counselor's work with the individual child had shown her that the children she knew were fitted neither for citizenship nor for industry, and that probably in this unfitness might be found many of the causes for future delinquency. To reach these causes, it would be necessary to go farther back into the child'slife. Accordingly, as an experiment, counselors were placed in two public schools whose work extended from the fifth through the eighth grade.

The coöperation of various social agencies in the city was enlisted until last year the resources of two hundred and thirty-six different agencies were brought to the help of the school children in whom the counselors were interested. Teachers are beginning to turn to these workers when children do not respond to teaching. After the work had been organized for the boys as well as for the girls, a teacher remarked, "We don't seem to have disciplinary 
problems in our room since you came to us." Yet almost in the same breath she told of a very naughty boy. "Your counselor visited the home," she said, "and found Jim sleeping on four chairs; he came to school without breakfast and had to steal food to keep soul and body together." He was to her mind not a disciplinary case, but a living boy with problems to solve far beyond his years and she was ready to help him solve them.

\section{The Factors Common to Teaching and Social Work}

So much for the background of an attempt to relate social worker and teacher. We are now ready to consider those factors, found in the school, that demand the services of a social worker, and to see how these factors enter into the work of the teacher and so bring together the teacher and the social worker. The social worker's problem is that of unadjusted social relationships. Are these to be found in any number in the schools, or are those which we have reviewed in the work of the White-Williams Foundation, isolated incidents?

The statistical report of the Philadelphia Board of Public Education for 1920 gave a school population of 296 ,573 , of which 42.7 per cent were of foreign parentage. There were 6,800 truants; 15 per cent of the children were "left down"; 7,834 children were three or more years behind the so-called normal grade; 2,109 were in special classes for backward children and 536 were in disciplinary classes.

The Junior Employment Service was able to secure 347 school records of the 908 in the study to which reference has already been made. These showed that 283 , or 81 per cent, had failed one or more times to pass their school grade. This would seem to indicate that many of the children who said that they did not like school, disliked it because they were unsuccessful in the work which they were given to do. If the percentage of failure for the 347 children held good for the entire 10,000, and it is probable that it did, since the 347 were not a selected group, it is evident not only that many of the children in school are not properly related to the school, as indicated by the figures of the report, but also that many of those who leave school, do so for this same reason.

One of the first things which impressed the counselors when they entered the school system, was the enormous number of children with whom it was dealing. They knew it in figures, but when they began to study Mary, Jennie, and the others as individuals, the numbers became appalling. Looked at from one angle, this vast army whom we educate is the glory of our public school system. It is certainly unique, for never before in the history of the world were there gathered together children from all nationalities on the face of the earth, to receive a common education. On the other hand, this same number of children becomes a curse; by blurring the teacher's vision, it prevents him from seeing the individual child. There is nobody interested in the "whole Johnnie," who used to be known because there were not so many of him.

\section{The Twentieth Century Develop- ment of These Factors}

Often we blame the schools for this neglect, but they are not entirely responsible since they have not had the time to catch up with the rapid growth of our country. Educators could scarcely foresee this vast increase in our population when they secured the legislation that has caused so many of our problems - the compulsory education law.

Such a law in the early part of the 
nineteenth century would not have complicated our school problem as it has today, because it would not have had to deal with the foreign language groups or with industrial and city problems. The seventeenth century immigrants of New England were eager that their children should learn to read and write, but too many of the later immigrants do not hold "book learning" in the same esteem, especially in a foreign tongue, because it seems to have no connection with home life or with earning a living; and not only the foreign parents but even the children of old American stock have become impatient with this book knowledge.

When one considers, also, that only a century and a quarter ago, most of our population was rural, that Philadelphia with its 60,000 inhabitants was then the largest city in the United States, that within this comparatively short space of time our great industrial centers have opened up and that most of the occupations of homemaking have necessarily been transferred to the factory then it becomes apparent that both the parent and the teacher must unite in offering to the child a worthy substitute for the old-time instructive home-tasks of spinning, weaving, carpentering and planning the construction of various complete articles for the household. Parents have been inclined to accept the ready-made existence of modern industrial life and are surprised to note the changes in the school curriculum which teachers must make in order to meet the constantly decreasing opportunities of the home. They cannot see why their boy needs an education different from that which was good enough for them. In the old days in the country, these parents had known the teacher who "boarded 'round." "Backgrounds and foregrounds" of the child's life were open to those teachers.
We have heard of the wonderful results secured by the teacher in the "little red school house." Was it not this understanding of his children, born of intimate personal knowledge, and the cooperation of the parents that made it possible for him to accomplish so much?

In the same way the teacher of today, like the parent, has taken for granted the intimate conditions which touch him. He has tried to teach the foreign child in the same way that he teaches the American, and too often he has applied to both the "system of education" which he has learned, regardless of the need of the child or the changing industrial conditions. He may know that he has children of five or six nationalities in his room, but he may not know the history and the customs of those nationalities or anything about the present homes of these children. He sees the parents only when they come to the school to complain and he is called to the principal's office to hear such complaint.

A teacher one day was trying to make an Italian child understand the word "up." "Up, up," she said. "Where you go when you sleep." The child kept saying "Down," and the teacher thought him stubborn, until she discovered that his family slept in the basement.

\section{How Teachers Are Dealing with These Factors}

In the face of these tremendous problems the school is not lying down but is going forward to meet them. In 1899 , in Philadelphia, special classes for backward children were first opened and the Statistical Report for 1920 gives 103 centers for this work. Last year a separate school building was opened under the direction of a psychologist employed in the fall of 1920 ; more re- 
cently, disciplinary classes were started, and three years ago a disciplinary school was opened. Other schools of the kind are planned for this year. The Statistical Report gives, in addition, a goodly number of classes for crippled, tubercular, anemic, partial sighted and non-English-speaking children.

The grading of the regular schools is being reviewed. Last year our psychologist found in one fifth grade, children whose mental ages ranged from eight to fifteen years, and this same room contained children with ability of third, fourth, fifth, sixth and seventh grades. When the school is large enough to permit several divisions of one class, the new method contemplates the grading of children according to mental age, correlated with chronological. For the hand-minded children, new opportunities are being offered in the junior high school. In Philadelphia, the first school of this kind has proved such a success that the Board of Public Education is organizing three additional junior high schools this fall. For those who are interested in trades, there are the new trade school for girls and the older trade departments for boys in the high schools.

To aid in this group handling of children and to meet the maladjusted relationships, the schools are attempting to study the individual child. The psychologist is examining children who do not come up to the grade requirements, and is planning the groups to fit their needs. In the Philadelphia schools last year the medical inspectors found, in round numbers, 180,000 physical defects, but they were able to secure the treatment of only 81,000 , because of the small number of nurses for follow-up work. An effort is being made to increase this number. ${ }^{1}$

\footnotetext{
${ }^{1}$ In 1921, the Board of Education granted 17 new supervisors and inspectors.
}

Can the Teacher Handle the Situation WITHOUT THE SOCIAL WORKER?

Before we take up the problem of truancy which has been less intimately part of the school work, it would now seem a fair question to ask whether these activities in the school which have just been outlined are not sufficient to adjust the relations between child and teacher, so that no other aid is needed.

In reviewing the remedies, the first criticism naturally is that there are not enough of them to estimate their value. Acknowledging this criticism, but for the moment assuming that the schools have funds to secure all the doctors needed to examine carefully each child, all the nurses to visit every home and instruct in hygiene as well as to urge the correction of defects, all the psychologists to grade children according to mental age correlated with chronological, all the psychiatrists to care for emotional maladjustments, and all the special classes and special schools for every kind of child, would there be any place for a social worker? The experiment of the White-Williams Foundation is showing that in the schools having these activities, the teachers are most desirous of securing social workers.

In 1919, Dr. J. H. Leuba of the Department of Psychology at Bryn Mawr College determined upon a study of the boys in Philadelphia's disciplinary school. He came to the Foundation for a social worker to help him. When the study was concluded, and both agencies withdrew, the principal urged the White-Williams counselor to continue her visits to the homes, saying that since he had known that kind of help, he felt that it was an essential part of the school work.

When the psychologist of the Department of Education entered the 
school system, she also felt that a social worker was essential in dealing with the backward children in the centers which she was opening, and the White-Williams Foundation gave her a counselor. At the same time, a principal of one of the most progressive high schools in Philadelphia who had secured the services of a psychologist, asked the Foundation for someone to visit thehomes and bring to the psychologist the social histories of the children. She said, "We have almost no social problems but we need to know about the child's home life, to diagnose properly his mental ability and to plan for his future." After less than six months of visiting in the homes by a counselor, she confessed, "I had no idea that there were so many social problems confronting our children, and I did not realize what a help the knowledge of the home would bring to our teachers."

These instances would indicate not only that there is room for a social worker in the public schools, but that these new activities are making the need of such a worker more apparent.

\section{Is the Teacher's Need of a Social} Worker Comparable to the

\section{DOCTOR's NeÉ?}

Little more than ten years ago, Dr. Richard C. Cabot discovered that the hospitals needed social workers. Just as educators are finding "repeaters" in our schools who have cost the schools many thousand dollars, so they found them in the hospitals. Money and space were being wasted, as they are in the schools, and the patients' time, often very precious to a working man or woman, was being consumed because no one with trained vision saw that the patient could continue with the right treatment in his home environment. The "backgrounds of hospital work"'

${ }^{2}$ Social Service and the Art of Healing-by Richard C. Cabot, 1909. as Dr. Cabot called them, were being neglected. In the home, the nurse's experienced eye saw Sarah's thin cheeks and hollow chest; her ear was alert to the mother's peculiar cough; but these same senses, untrained in the social field, could not detect the causes of distress which controlled the family situation. This visitor did not realize that possibly it was the father who must be given fresh courage--someone must help him find a job,--that Katie was bound to run wild, if her parents allowed her no recreation; that John would never be able to do his share towards the family support later on, unless someone got him off to school regularly and on time now.

Today, in private practice, the physician, the psychologist and the psychiatrist all want to know as much as possible about these social conditions before they will make a diagnosis; and in the schools, when there is time to give careful examinations, these specialists will increasingly ask for just this information. The teacher cannot give it to them. The nature of her problem has always been considered one of group handling and her whole course of training has been in group work. In practice it is impossible for her to visit the homes of from thirty to sixty children each semester and, if she could, on account of previous training her eye, like the nurse's, would not discover the facts which these specialists need.

Like them, and even more than they, she, too, must have this information and she must have it coördinated with theirs in order to see the "whole child." In the higher grades, where the work is departmental, and the teacher may all day long instruct different classes in arithmetic, she cannot individualize her pupils, and they become so many little heads, which are too often eager for the knowledge of a new kind of mischief, but not of decimals and frac- 
tions. To the doctor, these same children are diseased throats, eyes, ears, etc.; to the psychologist, they are I.Q's ranging from 40 to 140 . Frequently, these workers may not know the other's estimate of the child.

This problem of relationships and their coördination is distinctly that of the social worker. She cannot and she should not take the place of any of these specialists, but she can bring together their findings and, adding to this what she discovers of the child as a social being, she can make him an interesting, living personality to those who before saw only part of his mechanism. Especially must this be done for the teacher who, as she gets the vision, will see its value so plainly that she will want to know something herself of social case work. Already in the progressive normal schools hygiene and experimental psychology are being introduced, not that the teacher may diagnose disease or give mental tests, but that she may recognize the conditions which should be referred to doctor and psychologist. In the same way she must have training in social case work that she may be able to know which children need immediate social treatment and which she can herself help through changed methods of teaching.

\section{'The Attendance Officer's Rela- tion to Unadjusted School Conditrons}

The problem of truancy has been left until the last, since, in meeting it, the school has a worker who does visit the home and in whom there are unusual possibilities for adjusting relationships. Because the Bureau of Compulsory Education of Philadelphia offered its offices as a laboratory when the White-Williams Foundation entered the school system, the truant problem was the first which was brought to the attention of this organization.

In 1911, the department was reorganized by one of Philadelphia's school principals. He introduced modern school methods and so transformed its work that today it is considered one of the most progressive departments in the country, in spite of the fact that until 1921 there was only one attendance officer for every 8,000 of our population. ${ }^{3}$ Here again, there is the curse of numbers and no one now realizes this better than the chief of the department. He sees that truancy is not a unit character to be met by compulsion alone, but that the cause in each case must be found and treated. Last year, he helped to organize for his attendance officers a class in social case work, and by experimenting with social workers as attendance officers, he discovered how little real social work could be done if each worker must make from 30 to 60 visits a day with no continuous record of the child in his possession. Earlier he had assigned an attendance officer to one school with excellent results.

It has been suggested" that "schools, juvenile courts, corrective institutions, and child welfare agencies combine, simplify and improve" and that the new organization work through the schools. The chief of the Philadelphia Bureau of Compulsory Education would make a beginning by requiring that attendance officers be trained social workers, qualified for teaching. With the exception of ten or twelve to prosecute when necessary, he would change the name of attendance officer because of the police power which the present name implies; he would increase the number of officers so that there may be one in each school to work with the

${ }^{3}$ Last year, the Board of Education allowed 6 new officers.

" "That Child" by Henrietta S. Additon and Neva R. Deardorff, Survey, May 3, 1919. 
teachers, especially in the early grades where they may reach the causes of truancy before they become acute. As these counselors had time, they would take not only the children who are running away from school, but also those who are causing the teachers any trouble, since an absent mind is as impossible to educate as an absent body and may need more careful attention. Besides, when interest has gone, the body soon leaves too, and such a difficulty may be truancy in its incipient stage. At the end of eight years, when such an officer has grown up with the children and has secured the coöperation of the teachers and the help of the school office, there is every reason to believe that the problem of truancy will be practically solved.

\section{The Link Between Parent and Teacher}

Such a plan as this would not require great added expense in proportion to the whole school budget and is not the visionary dream of someone who does not know the schools; it has been outlined by a practical school man of large experience. It would also, to his mind, be the natural avenue for the introduction of social workers into the schools. In factories, large prices are paid for efficiency methods and these are adopted without question after it has been proved that, in the long run, money can be saved. In the school system, the methods proposed would probably not save money, but, far more, they would save manhood and womanhood, the manhood and womanhood of the old days of which we read, when the parent and the teacher worked hand in hand for the child. We should again link them together; but we cannot go backward. There must be a new link in the chain to unite the broken parts and experiment is teaching us that this link is the social worker. She will connect with the home not only the teachers, but also all the necessary forces of school and community for the help of the child.

\section{Summary}

To summarize what has been said: In the early days of our country, the center of the child's educational life was in the home. Parents who were obliged to report from time to time whether they were training their children "in learning and labor and other employments profitable to the Commonwealth," unconsciously so coordinated the child's physical, mental, emotional, social and vocational life that the "whole child" was understood and educated. As the center of his education gradually shifted to the school, and as specialists in addition to the teacher began to deal with the child, each one knew only a part of him and no one knew his background.

Once more, education is demanding the knowledge of the "whole child" in his environment before attempting to teach him. Today, the one coördinator of this "whole child" in home and school environment is the social worker. When all teachers have understanding of social case work, they will give this worker the welcome which is now accorded to her by those of their own number who already understand, and by socially minded physicians, psychiatrists and psychologists.

At present, it looks as if attendance departments would be the first to recognize the need of a social worker, but until some department of the school does see this need, the social workers in private organizations can do little more than present the picture of a few " whole children" to the school and to the community, so that popular opinion may recognize the value of the individual with his unknown potential power and give him, in the school, the opportunity to develop this power to the utmost. 